\title{
Contaminant-free cultivation of Pfiesteria shumwayae (Dinophyceae) on a fish cell line
}

\author{
Matthew W. Parrow ${ }^{1, *}$, JoAnn M. Burkholder ${ }^{1}$, Nora J. Deamer ${ }^{1}$, John S. Ramsdell ${ }^{2}$ \\ ${ }^{1}$ Center for Applied Aquatic Ecology, North Carolina State University, 620 Hutton Street, Suite 104, Raleigh, \\ North Carolina 27606, USA
}

${ }^{2}$ Marine Biotoxins Program, Center for Coastal Environmental Health and Biomolecular Research, National Oceanic \& Atmospheric Administration, National Ocean Service, 219 Fort Johnson Road, Charleston, South Carolina 29412-9110, USA

\begin{abstract}
Geographically distinct strains of the heterotrophic dinoflagellate Pfiesteria shumwayae were cultivated on a fish cell line in the apparent absence of bacteria and other microbial contaminants. Cultures were established with a high rate of success by inoculating single purified $P$. shumwayae cells into fish cell cultures containing a simple saltwater medium suitable for both cell types, and resulting isolates were serially cultivated on fish cells for months without visible signs of abnormality or reduced viability. P. shumwayae fed phagocytically on the fish cells and exhibited higher cell production than reported using other culturing methods. Compared to previous methods of studying the interaction between Pfiesteria spp. and fishes, this system enabled closer and more direct observation of the dinoflagellates and was also more economical and sustainable as a culturing method. The absence of bacteria and other contaminating microorganisms should facilitate important physiological and biochemical investigations. The methods used were inadequate for cultivating strains of $P$. piscicida, suggesting a possible difference in nutritional requirements between the 2 Pfiesteria species.
\end{abstract}

KEY WORDS: Pfiesteria spp. · Fish cell line · Dinoflagellate culture

\section{INTRODUCTION}

The dinoflagellate genus Pfiesteria presently consists of $P$. piscicida and $P$. shumwayae, 2 heterotrophic species found in brackish coastal waters. Over the past decade, instances of fish disease and death in cultures and estuarine waters of the mid-Atlantic US coast have been attributed to Pfiesteria spp. (Burkholder et al. 1992, 2001a,b,c, Noga et al. 1993, 1996, Marshall et al. 2000, Gordon et al. 2002). Toxin production and/or phagocytic feeding on fish epithelial cells are reported and recently debated mechanisms by which Pfiesteria spp. may harm or kill fishes, based primarily on studies in which living fish were exposed to the dinoflagellates or culture filtrates (Burkholder et al. 1992, 2001a,b,c, Noga et al. 1993, 1996, Marshall et al. 2000, Gordon et al. 2002, Quesenberry et al. 2002, Lovko et al. 2003). Without exacting precautions (i.e. Noga \& Bower 1987), the use of entire fish in such experimen- tal systems inevitably includes associated bacterial, fungal and protistan contaminants. Among these, certain bacteria might influence or participate in the production of toxic compounds (Shilo \& Aschner 1953, Bein 1954, Douglas et al. 1993, Bates et al. 1995, Gallacher et al. 1997, Hold et al. 2001), and contaminating microorganisms may also contribute directly to fish mortality as infective pathogens (Noga 2000). Thus, experimental systems that expose entire fish to Pfiesteria spp. also incorporate potential interactions with other microorganisms, which may complicate the investigation and restrict interpretations. Microbial contaminants also confound sustained cultivation of Pfiesteria spp. on living fish, and the differences of scale in size and motility between the dinoflagellates and fish can hinder direct microscopic observation. In an attempt to overcome these difficulties, a method was tested for culturing Pfiesteria spp. on an established fish cell line in the absence of bacteria and other cont- 
aminating microorganisms. A technique that proved successful for highly productive serial cultivation of $P$. shumwayae is described which might facilitate a more precise examination of some biological and biochemical interactions between Pfiesteria spp. and fishes.

\section{MATERIALS AND METHODS}

Dinoflagellate cultures. The Pfiesteria piscicida and $P$. shumwayae strains used in this study are listed in Table 1. Stock dinoflagellate cultures were maintained in 15 salinity synthetic seawater (Instant Ocean, Aquarium Systems) and were provided with cryptophyte cells (Rhodomonas sp. CCMP757; ProvasoliGuillard National Center for Culture of Marine Phytoplankton) as a food source (Parrow et al. 2002). The Pfiesteria spp. stock cultures had each been initiated with a single dinoflagellate cell, but were not bacteriafree. All culture manipulations and transfers were made under a positive-pressure laminar-flow hood using sterilized instruments, solutions and aseptic techniques (Hamilton 1973, Guillard 1995). All culturing procedures were conducted at 21 to $23^{\circ} \mathrm{C}$.

Fish cell culture. A heterologous fish cell line derived from Chinook salmon Oncorhynchus tshawytscha embryo tissues (CHSE) was used (American Type Culture Collection CRL-1681). The CHSE cell line was reportedly free of microbial contaminants including mycoplasmas (Lannan et al. 1984) and grew as an adherent layer of epithelioid cells 1 or more cells thick. CHSE cells were grown in Eagle's minimum essential medium (MEM) (Sigma M4655) with 10\% fetal bovine serum (FBS) (Sigma F0926) in horizontal 25 or $75 \mathrm{~cm}^{2}$ polystyrene cell-culture flasks (Corning) with 10 or $50 \mathrm{ml}$ of medium, respectively. Confluent CHSE cell layers were disaggregated for subculturing by treatment with $0.05 \%$ trypsin-EDTA solution (Sigma T3924) for $20 \mathrm{~min}$, followed by tapping of the flask on the

Table 1. Pfiesteria spp. Strains tested for growth on CHSE (Chinook salmon embryo) cells, geographical source locations, and collection dates

\begin{tabular}{|c|c|c|}
\hline $\begin{array}{l}\text { Strain } \\
\text { designation }\end{array}$ & Source location & $\begin{array}{l}\text { Collection } \\
\text { date }\end{array}$ \\
\hline \multicolumn{3}{|c|}{ Pfiesteria piscicida } \\
\hline CCMP2362 & Off Flanner Beach, Neuse River, NC, USA & Sep 1997 \\
\hline CCMP1832 & Chicamacomico River, MD, USA & Jan 1998 \\
\hline CCMP2363 & Marsh Side Pond, Hilton Head Island, SC, USA & Apr 2002 \\
\hline CCMP2423 & Beard Creek, Neuse River, NC, USA & May 2002 \\
\hline \multicolumn{3}{|c|}{ Pfiesteria shumwayae } \\
\hline CCMP2357 & Carolina Pines, Neuse River, NC, USA & Jul 1998 \\
\hline CCMP2089 & Pamlico River, NC, USA & Nov 1999 \\
\hline CCMP2359 & Marshall Creek, Chesapeake Bay, MD, USA & Aug 2000 \\
\hline CCMP2360 & Tasman Bay, New Zealand & Apr 2000 \\
\hline
\end{tabular}

counter to dislodge the cells. The disaggregated cells were then suspended in fresh medium and cultures were split at a 1:5 ratio into new flasks. Sterile, filtered $\left(0.22 \mu \mathrm{m}\right.$ pore size) air with $5 \% \mathrm{CO}_{2}$ was added as a gas-phase buffer prior to sealing each flask (Freshney 1986). Transferred CHSE cells grew to a confluent layer in 5 to $6 \mathrm{~d}$ and a subset of cultures was transferred for further propagation every $7 \mathrm{~d}$.

Purification of Pfiesteria spp. cells. Dinoflagellate cells from the stock cultures were purified by 'washing' individual specimens through several drops of sterile medium using a finely pulled glass micropipette (Pringsheim 1946, Droop 1954, Caron 1993, Guillard 1995).

Micromanipulations were made by hand using an inverted compound microscope (Olympus CK40) placed in the laminar-flow hood; all contact surfaces and instruments used in the procedure were sterilized by heat if possible, or $95 \%$ ethyl alcohol. Micropipettes were equipped prior to use with a sterilized aspiration device modified from Guillard (1995), fitted with a $0.22 \mu \mathrm{m}$ pore size in-line filter (Caron 1993). Individual Pfiesteria spp. flagellates were isolated from petri dish subcultures and dispensed into a drop of $0.22 \mu \mathrm{m}$ filtered 12 salinity synthetic seawater (Instant Ocean) containing $0.5 \%$ methyl cellulose on a microscope slide. The isolated cell was allowed to swim for 2 to 3 min, during which time the micropipette was thoroughly rinsed with $95 \%$ ethyl alcohol and then refilled with sterile medium. Each cell was then re-isolated into a new drop, transferring as little medium as possible along with it, and this 'washing' process was repeated 8 to 12 times per cell. If the specimen became nonmotile (a temporary cyst) during the procedure, it was transferred from drop to drop as a nonmotile cell. The washed dinoflagellate cell was then deposited into a prepared culture flask containing 6 to $9 \mathrm{~d}$ old CHSE cells (see next subsection). At least 2 cells from each of the $P$. piscicida and $P$. shumwayae strains listed in Table 1 were isolated and purified in this fashion and deposited individually into separate flasks containing CHSE cells.

To provide a larger inoculum of purified dinoflagellate cells, a sample of CCMP2362 Pfiesteria piscicida cysts was purified using Percoll silica (Sigma P4937) density-gradient centrifugation and antibiotics (Oestmann \& Lewis 1995, Cho et al. 2002). A stock CCMP2362 culture flask containing abundant cysts was rinsed with sterile deionized water (DI) to remove the swimming cells, and the cysts were then dislodged with a plastic cell 
scraper, collected in $1 \mathrm{ml}$ of DI in a centrifuge tube, and placed in an ultrasonic water bath (Fisher Scientific $\mathrm{FS} 2 \mathrm{OH}$ ) for $1 \mathrm{~min}$ to disaggregate the cysts from bacteria and debris. The cysts (ca. $3.0 \times 10^{4}$ ) were then placed on the surface of a stepwise 10, 20, 30, 40, 50\% gradient of Percoll silica in DI composed of $1.5 \mathrm{ml}$ layers in a $15 \mathrm{ml}$ centrifuge tube, and pelleted $(2000 \times g$, $15 \mathrm{~min})$. The pelleted cysts were then recovered, resuspended in DI, and the sonification and Percollgradient centrifugation steps were repeated twice. The cysts were incubated for $48 \mathrm{~h}$ in DI containing amphotericin B $\left(0.50 \mu \mathrm{g} \mathrm{ml}^{-1}\right)$, penicillin $\left(200 \mathrm{IU} \mathrm{ml}^{-1}\right)$, and streptomycin $\left(0.2 \mathrm{mg} \mathrm{ml}^{-1}\right)$, washed twice by centrifugation, and incubated for another $48 \mathrm{~h}$ in DI containing amoxicillin $\left(0.3 \mathrm{mg} \mathrm{ml}^{-1}\right)$, bacitracin $\left(0.4 \mathrm{mg} \mathrm{ml}^{-1}\right)$, carbenicillin $\left(300 \mu \mathrm{g} \mathrm{ml}^{-1}\right)$, erythromycin $\left(0.3 \mathrm{mg} \mathrm{ml}^{-1}\right)$, and bactopeptone $\left(0.2 \mathrm{mg} \mathrm{ml}^{-1}\right)$ to promote antibiotic activity through bacterial growth (Droop 1967). The cysts were then washed once in DI by centrifugation and added to a flask containing 6 to $9 \mathrm{~d}$ old CHSE cells (see next subsection).

Establishment and cultivation of Pfiesteria spp. on CHSE cells. Preliminary observations indicated that the MEM + FBS medium used to propagate the CHSE cells was not tolerated by the dinoflagellates. Therefore, the medium overlying the CHSE cell layer was replaced with an equivalent volume of 10 salinity synthetic seawater (Instant Ocean) supplemented with $f / 2$ trace elements and $2 \times f / 2$ vitamins (Guillard 1975) prior to adding the purified Pfiesteria spp. cell(s). This medium (SSF) approximated the osmolarity of the CHSE growth medium and was also suitable for the dinoflagellates. CHSE culture flasks that had been inoculated with Pfiesteria spp. were examined daily for dinoflagellate proliferation and evidence of microbial contamination. Cultures in which the dinoflagellates proliferated and microbial contaminants were not evident were subcultured after 11 to $14 \mathrm{~d}$ into new flasks containing CHSE cells in SSF medium. Once established, the dinoflagellate strains were subcultured every $7 \mathrm{~d}$ by transferring $100 \mu \mathrm{l}$ (ca. 1.5 to $2.5 \times 10^{4}$ dinoflagellate cells) into $25 \mathrm{~cm}^{2}$ flasks containing $7 \mathrm{~d}$ old CHSE cells in SSF medium. The gross impact of dinoflagellates on CHSE cell layers was assessed over time by examining these flasks daily during routine cultivation. Replicate CHSE cultures were incubated in SSF medium alone for $7 \mathrm{~d}$ as negative (comparison) controls.

Sterility tests. Pfiesteria spp. strains cultivated on CHSE cells were examined for microbial contaminants by test culture in enriched broths and on solid medium and by direct epifluorescence microscopic examination of culture subsamples stained with the DNA fluorophore DAPI. Enrichments of 10 salinity L1 medium were used as test broths: (1) bactopeptone $\left(0.5 \mathrm{~g} \mathrm{l}^{-1}\right)$, yeast extract $\left(0.5 \mathrm{~g} \mathrm{l}^{-1}\right)$, and glucose $\left(0.5 \mathrm{~g} \mathrm{l}^{-1}\right)$ as a general test for bacteria and fungi, and (2) bactopeptone $\left(1.0 \mathrm{~g} \mathrm{l}^{-1}\right)$ and methylamine $\cdot \mathrm{HCl}\left(1.0 \mathrm{~g} \mathrm{l}^{-1}\right)$ as a test for methylaminotrophic bacteria (Guillard 1995). Solid medium was $0.5 \times$ marine agar composed of Difco 2216-enriched agar (27.6 $\mathrm{g} \mathrm{l}^{-1}$ ) (Becton Dickinson), agar $\left(7.5 \mathrm{~g} \mathrm{l}^{-1}\right)$, bactopeptone $\left(5 \mathrm{~g} \mathrm{l}^{-1}\right)$, and yeast extract $\left(1 \mathrm{~g} \mathrm{l}^{-1}\right)$ in deionized water. Duplicate samples $(1 \mathrm{ml})$ from late growth phase ( 7 to $10 \mathrm{~d}$ ) cultures that visually appeared free of contaminants $(400 \times$, Hoffman modulation contrast) were inoculated into $20 \mathrm{ml}$ broth tubes and onto agar plates. Test media were inoculated with samples from the original stock Pfiesteria spp. cultures (containing bacteria) as positive controls for contaminant growth, and un-inoculated test media served as negative controls. Test media were incubated at $21^{\circ} \mathrm{C}$ in darkness and checked daily over $4 \mathrm{wk}$ for broth cloudiness and other visible signs of contaminant growth. These tests were repeated at 2 mo intervals.

Dinoflagellate cultures that had been serially transferred onto CHSE cells for at least 4 mo without visible contaminants or demonstrable contaminants using test media were examined for the presence of bacteria using epifluorescence microscopy after DAPI-staining and filtration (Hobbie et al. 1977, Turley 1993). Subsamples $(2 \mathrm{ml})$ from 7 to $10 \mathrm{~d}$ old cultures were fixed with glutaraldehyde (1\% final concentration), stained with DAPI ( $5 \mu \mathrm{g} \mathrm{ml}^{-1}$ final concentration) in darkness for $30 \mathrm{~min}$, and filtered onto $25 \mathrm{~mm} 0.2 \mu \mathrm{m}$ pore-size GTBP black polycarbonate filters (Millipore). Each filter was placed on a microscope slide, covered with a drop of non-fluorescent immersion oil (Cargille type FF) and a cover slip, and examined with an Olympus AX70 microscope using mercury vapor lamp epi-illumination, a DAPI fluorescence filter set, and a $60 \times 1.2 \mathrm{NA}$ water immersion objective. Samples from the original stock dinoflagellate cultures (containing bacteria) prepared in the same fashion were examined as positive controls for DAPI-stained contaminants. At least 30 fields of view per sample were examined.

Dinoflagellate population growth measurements. Pfiesteria shumwayae strains (CCMP2089, 2359, and 2360 ) that had previously been cultivated on CHSE cells for 3 to 9 mo were inoculated at an initial density of ca. $2.0 \times 10^{3}$ dinoflagellate cells $\mathrm{ml}^{-1}$ into triplicate $75 \mathrm{~cm}^{2}$ flasks containing $8 \mathrm{~d}$ old CHSE cell layers overlain with $50 \mathrm{ml}$ of SSF medium. The cultures were gently mixed and subsampled (1 ml) initially and at subsequent $24 \mathrm{~h}$ intervals for $12 \mathrm{~d}$. Samples were preserved with 1\% (final concentration) acidic Lugol's solution and dinoflagellate cells were enumerated by light microscopy (400x) using a Palmer-Maloney counting chamber (Wetzel \& Likens 1991). Reproductive cysts were each counted as 1 cell, regardless of cell divisional state. Population growth ( $k$, divisions $\mathrm{d}^{-1}$ ) was estimated from 
successive counts over the exponential phase of growth by computing the least-squares regression slope of semilogarithmic daily cell count means, as in Guillard (1973). $P$. shumwayae isolates in routine cultivation were randomly sampled for cell enumeration as above after $7 \mathrm{~d}$ growth on CHSE cells (prior to subculturing) to estimate cell yield among isolates. A Student's t-test assuming unequal variances was used to test for differences between treatments in maximum cell abundance and estimated division rate $(\mathrm{p}<0.05)$.

\section{RESULTS AND DISCUSSION}

\section{Pfiesteria strains cultivated on fish cells}

In this culturing system, an adherent layer of fish cells was provided to Pfiesteria spp. as a food source. Similar methods have been used to cultivate and study Amyloodinium ocellatum, a dinoflagellate ectoparasite of marine fishes (Noga 1987, Oestmann \& Lewis 1996). The technique depended on use of a medium suitable for both the dinoflagellates and the CHSE cells. The euryhaline tolerance of Pfiesteria spp. (Sullivan \& Andersen 2001) permitted use of a simple synthetic seawater medium approximating the osmolarity of the CHSE growth medium. The medium was supplemented with vitamins ( $\mathrm{B}_{12}$, thiamine and biotin) and trace elements in case any of these were required or stimulatory for growth of the dinoflagellates (Gaines \& Elbrächter 1987, Lessard 1993). The CHSE cells tolerated this medium; replicate $7 \mathrm{~d}$ old CHSE cell layers incubated in SSF medium for $7 \mathrm{~d}$ appeared normal (but displayed increasingly granular cytoplasm over time), and could also then be transferred and subcultured in MEM plus FBS medium following the incubation. Thus, the SSF medium was not lethal to the CHSE cells, allowing living fish cells to be incubated with the dinoflagellates and subsequent damage to the cell layer to be directly attributed to dinoflagellate activity.

Isolates were established from each of the tested Pfiesteria shumwayae strains and have since been serially cultivated on CHSE cells for 6 to 12 mo (Table 2) without signs of morphological aberrancy or reduced

Table 2. Pfiesteria shumwayae. Strains cultivated on CHSE cells, number of contaminant-free isolates obtained from each strain, and duration in serial cultivation at the time of this report

\begin{tabular}{|lcc|}
\hline Strain designation & No. of isolates & Duration (mo) \\
\hline CCMP2359 & 2 & 12 \\
CCMP2357 & 2 & 9 \\
CCMP2360 & 2 & 6 \\
CCMP2089 & 1 & 6 \\
\hline
\end{tabular}

viability. Of 10 individual purified $P$. shumwayae cells, 7 proliferated to produce sustained populations on CHSE cells, demonstrating a high rate of success with the methods employed. In contrast, the tested strains of $P$. piscicida were not successfully cultivated using these methods. Although some isolated $P$. piscicida cells were observed apparently feeding on the CHSE cells and limited proliferation occurred, the resulting low number of dinoflagellates did not grow well and could not be subcultured. The sample of $P$. piscicida cysts purified by density-gradient centrifugation and antibiotics produced numerous flagellates within $1 \mathrm{~d}$ of inoculation into CHSE culture, and flagellates were observed apparently feeding on the CHSE cell layer. However, as in the single-cell isolations, subcultured populations failed to proliferate sufficiently for serial cultivation. There are several possible causes of this apparent difference in culture requirements between the 2 Pfiesteria species. P. piscicida may have required some metabolite(s) that was (were) missing from the system (e.g. Droop \& Doyle 1966), or there could have been a difference between the species in a feeding parameter related to the CHSE cells. For example, it was reported that 2 strains of Amyloodinium ocellatum required different types of fish cells for cultivation (Oestmann \& Lewis 1996).

\section{Purity of cultures}

The 7 isolates of Pfiesteria shumwayae cultivated on CHSE cells (Table 2) were established without any visible bacterial or fungal contaminants. These cultures also did not elicit detectable bacterial or fungal growth in enriched test broths or on solid media, whereas all test media inoculated with samples from the original dinoflagellate stock cultures showed obvious contaminant growth (broth cloudiness and colony formation on solid medium) within days. Likewise, DAPI-stained samples from the original dinoflagellate stock cultures contained abundant fluorescent bacterial cells (rods and cocci) in every field of view, whereas no such contaminants were apparent in DAPI-stained samples from the 7 isolates of $P$. shumwayae cultivated on CHSE cells. Thus, the cultures were demonstrably free of microbial contaminants, and have remained so by these criteria since establishment. Representative CHSE culture flasks inoculated with single-washed $P$. piscicida cells also remained free of visible contaminants. Thus micropipette 'washing' of individual cells appeared successful as a technique for ridding Pfiesteria spp. cells of microbial contaminants, indicating that the isolated Pfiesteria spp. flagellate cells lacked tenaciously attached bacteria (Pringsheim 1946, Droop 1954). Endocytic bacteria within the $P$. shumwayae or 
CHSE cells were unlikely unless they were uncultivable outside the eukaryotes using these methods. However, the possibility that poorly culturable bacterial contaminants occurred at such low abundances as to avoid detection by these methods could not be entirely excluded. Future tests for the presence of bacterial gene fragments could provide additional information on this possibility.

\section{Dinoflagellate feeding and reproduction}

Feeding by Pfiesteria shumwayae on living fish surficial tissues has been previously described (e.g. Burkholder et al. 2001a,b); this culturing technique enabled simple microscopic observation of the process. Individual $P$. shumwayae flagellates attached to fish cells by an extensible feeding tube (generally called a peduncle; Elbrächter 1991b), through which fish cytoplasm was aspirated into the dinoflagellate food vacuole (Figs. 1 \& 2). The dinoflagellates often en- larged considerably during ingestion, sometimes doubling in length as the food vacuole swelled to occupy a majority of the cell. The feeding process only required seconds to minutes for completion (Fig. 2), after which the feeding tube was stretched thin, detached, and retracted as the dinoflagellate swam away. Based on observations of feeding and the amount of material ingested by some $P$. shumwayae cells, it appeared that the cytoplasm of more than 1 fish cell could be consumed in a single feeding act. No visible fish cell plasma membrane was left behind after feeding, as in true myzocytosis sensu Schnepf \& Deichgräber (1983). Flagellate cells already containing food vacuoles full of fish cytoplasm were sometimes observed to feed again, and dinoflagellates full of ingested fish cytoplasm appeared to often swim for hours before becoming nonmotile (encysting) for further digestion and cell division.

Stages of Pfiesteria shumwayae reproductive cell divisions were readily observed on culture substrata (Fig. 3A). The protoplast of nonmotile reproductive
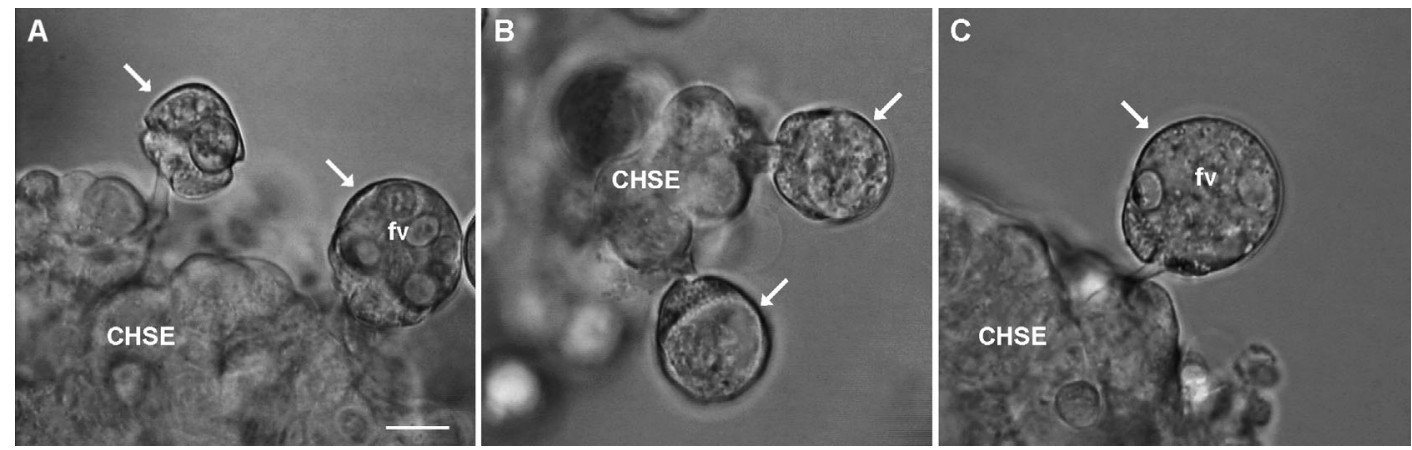

Fig. 1. Pfiesteria shumwayae. Photomicrographs of live flagellates feeding on Oncorhynchus tshawytscha (CHSE) cells. (A) Feeding cells (arrows); extended feeding tube of left cell can be seen attached to CHSE cells; cell on right has enlarged food vacuole (fv) containing ingested fish cytoplasm. (B) Feeding cells (arrows) attached to CHSE cells. (C) Feeding cell (arrow) attached to CHSE cells, with enlarged food vacuole (fv) containing ingested fish cytoplasm. Scale bar $=10 \mu \mathrm{m}$
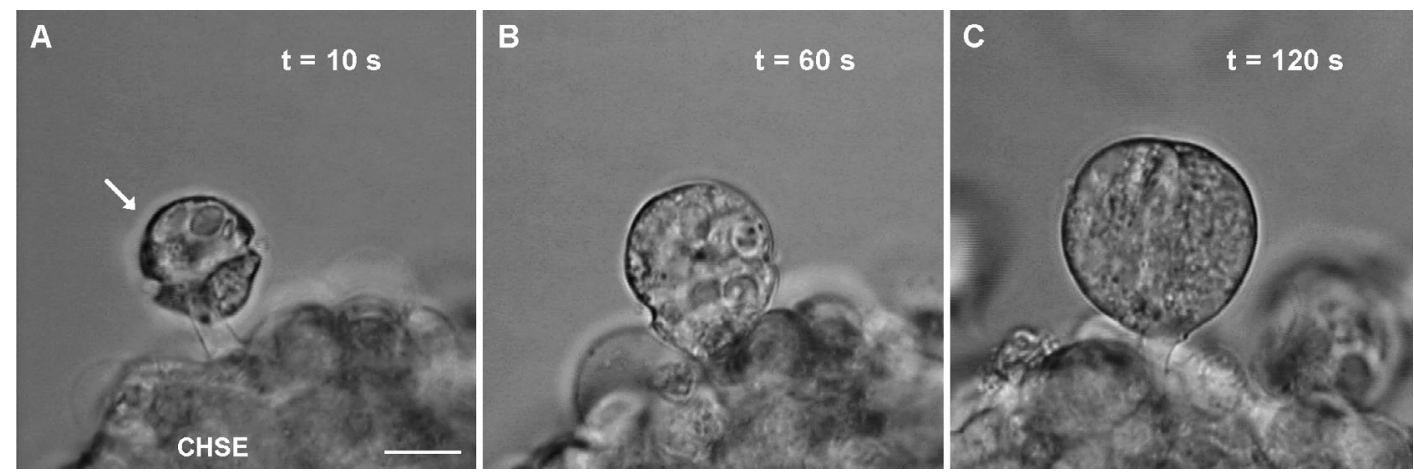

Fig. 2. Pfiesteria shumwayae. Sequential photomicrographs showing time series of observations on an individual flagellate cell feeding on Oncorhynchus tshawytscha (CHSE) cells. (A) Flagellate cell (arrow) 10 s after extension of feeding tube and attachment to CHSE cells; (B) flagellate cell $60 \mathrm{~s}$ later, now enlarged from ingestion of fish cytoplasm; (C) flagellate cell $120 \mathrm{~s}$ after attachment to CHSE cells, further enlarged from ingestion. Feeding tube was detached and the cell swam away $<10 \mathrm{~s}$ after (C). 

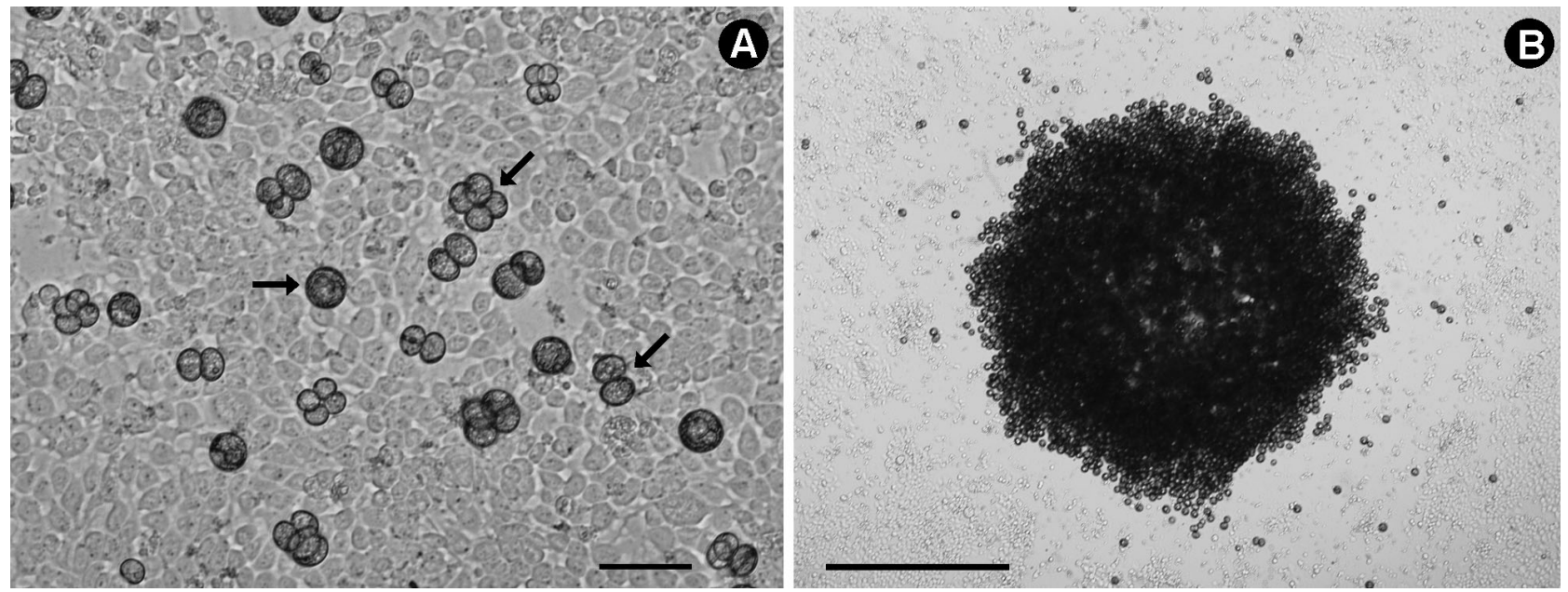

Fig. 3. Pfiesteria shumwayae and Oncorhynchus tshawytscha (CHSE). Photomicrographs of cultured cells. (A) P. shumwayae nonmotile cells (cysts) undergoing cell divisions (arrows), occurring on CHSE cell layer (background). Scale bar $=50 \mu \mathrm{m}$.

(B) Representative aggregation of cysts found in CCMP2357 cultivated on CHSE cells. Scale bar $=500 \mu \mathrm{m}$

cells (division cysts) underwent 1 to 4 consecutive cell divisions that resulted in 2 to 16 flagellate offspring cells, confirming previous observations of $P$. shumwayae reproduction (Parrow \& Burkholder 2003b). With the exception of CCMP2357, the P. shumwayae reproductive cysts were distributed and not adherent to the culture substratum; gentle agitation was sufficient to suspend the cysts. These observations in contaminant-free cultures suggest that the reported adherent nature of $P$. shumwayae cysts (Parrow \& Burkholder 2003b) may be more related to an association with microbial biofilms than to an inherent adhesive capability. Unlike the other strains, the dinoflagellates in both isolates of CCMP2357 consistently formed concentrated, roughly circular aggregations of cysts up to $3 \mathrm{~mm}$ in diameter (Fig. 3B). These cyst aggregations also could be separated from the culture substratum by gentle agitation. The reason for this consistent difference in encystment behavior between the CCMP2357 isolates and the others was unknown. Active clustering of cells during temporary encystment occurs for unknown reasons and by unknown mechanisms in several genera of dinoflagellates (Lombard \& Capon 1971, Ucko et al. 1997, Garcés et al. 1998, Parrow et al. 2002, Parrow \& Burkholder 2003a).

\section{Pfiesteria shumwayae population growth and cell yields}

Pfiesteria shumwayae isolates grown on CHSE cells in $75 \mathrm{~cm}^{2}$ flasks containing $50 \mathrm{ml}$ of medium reached maximum densities of $1.4 \pm 0.3 \times 10^{5}$ to $2.8 \pm 0.6 \times 10^{5}$ dinoflagellate cells $\mathrm{ml}^{-1}$ (mean \pm SD) within 7 to $10 \mathrm{~d}$ (Fig. 4). CCMP2089 exhibited a significantly higher division rate (Fig. 5) and maximum cell abundance
(Fig. 4) than the other strains in this trial. Similar final densities of $2.4 \pm 0.7 \times 10^{5}$ dinoflagellate cells $\mathrm{ml}^{-1}$ were measured among isolates after $7 \mathrm{~d}$ of growth in the $25 \mathrm{~cm}^{2}$ flasks (containing $10 \mathrm{ml}$ of medium) that were used in routine cultivation $(\mathrm{n}=27)$. P. shumwayae cell yield in this cultivation system was probably most dependent on the area of the fish cell layer (since layer thickness was relatively constant), rather than on the volume of medium overlaying it. The measured dinoflagellate cell densities corresponded to an estimated yield of $9.7 \pm 3.0 \times 10^{4}$ dinoflagellate cells produced $\mathrm{cm}^{-2}$ of CHSE cells in $25 \mathrm{~cm}^{2}$ flasks. The maximum $P$. shumwayae cell densities obtained using this method were up to 10 -fold higher than those reported when using living fishes or cryptophyte microalgae as the food source (Burkholder et al. 2001a, Vogelbein et al.

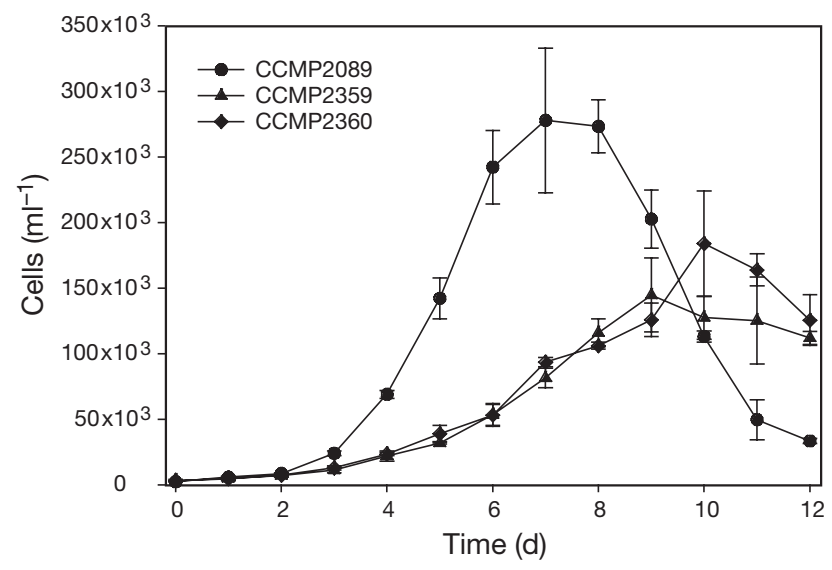

Fig. 4. Pfiesteria shumwayae. Time-course of cell densities for strains CCMP2089, 2359 and 2360 cultivated on Oncorhynchus tshawytscha cells in $50 \mathrm{ml}$ batch cultures. Data points are replicate $(n=3)$ means $\pm S D$ 


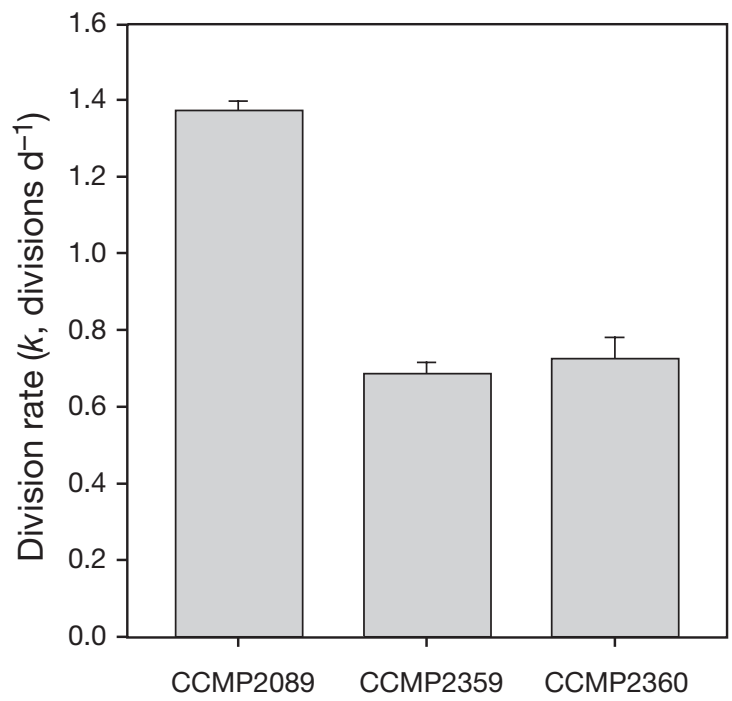

Fig. 5. Pfiesteria shumwayae. Mean $(+\mathrm{SD})$ division rates $(k$, divisions $\mathrm{d}^{-1}$ ) estimated during logarithmic growth phase for strains CCMP2089, 2359 and 2360 cultivated on Oncorhynchus tshawytscha cells in $50 \mathrm{ml}$ batch cultures

2001, Parrow et al. 2002), suggesting that the culture conditions in this system were well-suited to dinoflagellate proliferation. More complete sampling of encysted cells compared to previous methods may have also contributed to higher measured cell abundance.

\section{Effect of Pfiesteria shumwayae on CHSE cell layers}

Initially the CHSE cell layer exposed to Pfiesteria shumwayae formed a confluent layer of fish cells covering the flask bottom (Fig. 6A). The CHSE cell layer became increasingly damaged and patchy over time as the dinoflagellates fed and reproduced, and within 4 to 5 d large areas denuded of fish cells were apparent (Fig. 6B). Once the dinoflagellate population reached maximum density (typically in 6 to $8 \mathrm{~d}$ ) the culture flask was completely denuded of CHSE cells, and all that remained on the culture substratum were abundant Pfiesteria shumwayae cysts, empty cyst walls and small bodies that appeared to be egested food remnants (viz. dinoflagellate feces; Elbrächter 1991a) (Fig. 7). Exposure to higher abundances of $P$. shumwayae cells resulted in more rapid destruction of the CHSE cell layer. The absence of other microorganisms, together with negative controls, allowed the observed damage to the CHSE cell layer to be attributed directly to the activity of $P$. shumwayae.

Previous studies reported that filtrates from some Pfiesteria spp. cultures contained dissolved compound(s) capable of injuring or killing fishes and molluscs (Burkholder et al. 1992, Noga et al. 1993, Gordon et al. 2002, Springer et al. 2002). Other studies attributed fish mortality to feeding activity by $P$. shumwayae (Lovko et al. 2003), or reported apparent synergistic effects of feeding activity and dissolved toxin(s) (Burkholder et al. 2001a, Gordon \& Dyer 2005). Unlike previous methods, the culturing system described here allows investigation of $P$. shumwayae as a fish pathogen without potential interference from other microorganisms. Other studies on the biology and ecology of the dinoflagellate might also be simplified by these conditions compared to those using entire living fishes. Disadvantages of this culture technique as an experimental system for estimating impacts of the dinoflagellates on living fishes include lack of a specific bioassay endpoint (i.e. fish death), and restricted ecological relevance due to system artificiality.
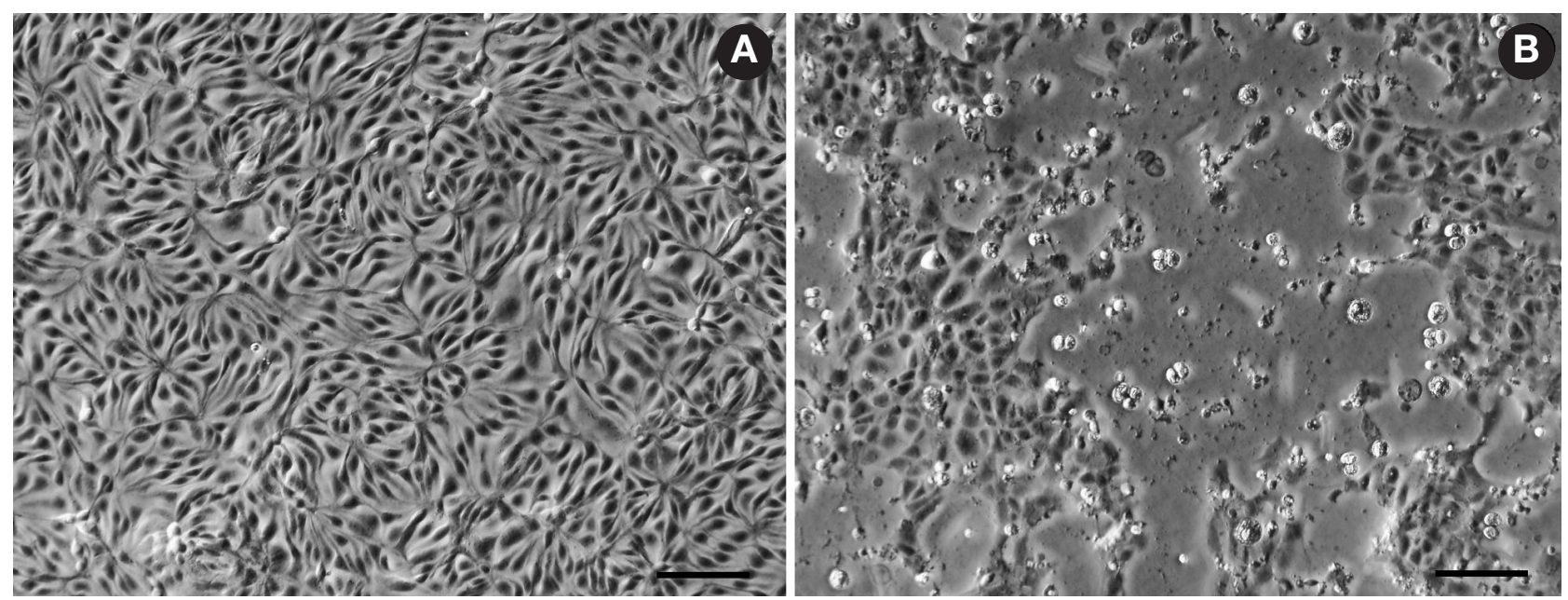

Fig. 6. Oncorhynchus tshawytscha and Pfiesteria shumwayae. Photomicrographs (Hoffman modulation contrast) of cultured cells. (A) Confluent fish cell layer of same age as (B), for comparison; (B) fish cell layer after exposure to growing $P$. shumwayae population for $4 \mathrm{~d}$, showing damage caused by dinoflagellates. Both scale bars $=100 \mu \mathrm{m}$ 


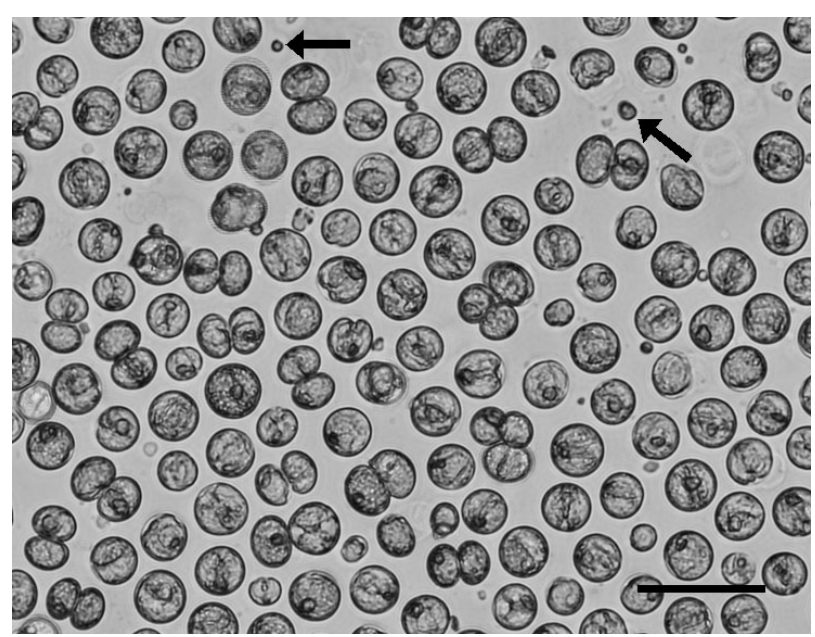

Fig. 7. Pfiesteria shumwayae. Photomicrograph of cysts and egested food bodies (arrows) remaining on culture flask substratum after consumption of the fish cell layer. Scale bar $=50 \mu \mathrm{m}$

\section{CONCLUSIONS}

Methods have been described for the establishment and sustained cultivation of Pfiesteria shumwayae strains on a fish cell line in the demonstrable absence of bacteria and other contaminating microorganisms. The techniques required minimal support equipment and reduced space, time and expense compared to previous methods of cultivating $P$. shumwayae on living fishes. The culture system was also more highly controlled and easily sustained due to the lack of microbial contaminants, and resulted in higher $P$. shumwayae cell densities than previously reported using other culture techniques. In addition, the cultureflask format enabled close microscopic observation of the dinoflagellates. $P$. piscicida was not successfully cultivated using these methods, indicating a possible difference in growth requirements between the Pfiesteria species that awaits further investigation. This culture system may facilitate studies that could advance understanding of the biology of Pfiesteria spp. and the potential impact of the dinoflagellates on living fishes.

Acknowledgements. We thank S. Dover of NOAA-NOS for technical support. Funding for this research was provided by the US Department of Commerce, NOAA, and the North Carolina General Assembly.

\section{LITERATURE CITED}

Bates SS, Douglas DJ, Doucette GJ, Léger C (1995) Enhancement of domoic acid production by reintroducing bacteria to axenic cultures of the diatom Pseudo-nitzschia multiseries. Nat Toxings 3:428-435
Bein SJ (1954) A study of certain chromogenic bacteria isolated from 'red tide' water with a description of a new species. Bull Mar Sci Gulf Caribb 4:110-119

Burkholder JM, Noga EJ, Hobbs CW, Glasgow HB, Smith SA (1992) New 'phantom' dinoflagellate is the causative agent of major estuarine fish kills. Nature 358:407-410

Burkholder JM, Glasgow HB, Deamer-Melia N (2001a) Overview and present status of the toxic Pfiesteria complex (Dinophyceae). Phycologia 40:186-214

Burkholder JM, Glasgow HB, Deamer-Melia NJ, Springer J, Parrow MW, Zheng C, Cancellieri PJ (2001b) Species of the toxic Pfiesteria complex, and the importance of functional type in data interpretations. Environ Health Perspect 109:667-679

Burkholder JM, Marshall HG, Glasgow HB, Seaborn DW, Deamer-Melia NJ (2001c) The standardized fish bioassay procedure for detecting and culturing actively toxic Pfiesteria, used by two reference laboratories for Atlantic and Gulf Coast states. Environ Health Perspect 109:745-756

Caron DA (1993) Enrichment, isolation, and culture of freeliving heterotrophic flagellates. In: Kemp PF, Sherr BF, Sherr EB, Cole JJ (eds) Handbook of methods in aquatic microbial ecology. CRC Press, Boca Raton, FL, p 77-89

Cho JY, Choi JS, Kong IS, Park SI, Kerr RG, Hong YK (2002) A procedure for axenic isolation of the marine microalga Isochrysis galbana from heavily contaminated mass cultures. J Appl Phycol 14:385-390

Douglas DJ, Bates SS, Bourque LA, Selvin RC (1993) Domoic acid production by axenic and non-axenic cultures of the pennate diatom Nitzschia pungens f. multiseries. In: Smayda TJ, Shimizu Y (eds) Toxic phytoplankton blooms in the sea. Elsevier, Amsterdam, p 595-600

Droop MR (1954) A note on the isolation of small marine algae and flagellates for pure cultures. J Mar Biol Assoc UK 33: 511-514

Droop MR (1967) A procedure for routine purification of algal cultures with antibiotics. Br Phycol Bull 3:295-297

Droop MR, Doyle J (1966) Ubiquinone as a protozoan growth factor. Nature 212:1474-1475

Elbrächter M (1991a) Faeces production by dinoflagellates and other small flagellates. Mar Microb Food Webs 5: 189-204

Elbrächter M (1991b) Food uptake mechanisms in phagotrophic dinoflagellates and classification. In: Patterson DJ, Larsen $J$ (eds) The biology of free-living heterotrophic flagellates. Systematics Association Special Vol No 45, Clarendon Press, Oxford, p 303-312

Freshney RI (1986) Animal cell culture: a practical approach. IRL Press, Oxford

Gaines G, Elbrächter M (1987) Heterotrophic nutrition. Bot Monogr 21:224-268

Gallacher S, Flynn KJ, Franco JM, Brueggemann EE, Hines HB (1997) Evidence for production of paralytic shellfish toxins by bacteria associated with Alexandrium spp. (Dinophyta) in culture. Appl Environ Microbiol 63:239-245

Garcés E, Delgado M, Masó M, Camp J (1998) Life history and in situ growth rates of Alexandrium taylori (Dinophyceae, Pyrrophyta). J Phycol 34:880-887

Gordon AS, Dyer B (2005) Relative contribution of exotoxin and micropredation to ichthyotoxicity of 2 strains of Pfiesteria shumwayae (Dinophyceae). Harmful Algae 4:423-431

Gordon AS, Dyer BJ, Seaborn D, Marshall HG (2002) Comparative toxicity of Pfiesteria spp., prolonging toxicity of $P$. piscicida in culture and evaluation of toxin(s) stability. Harmful Algae 1:85-94

Guillard RRL (1973) Division rates. In: Stein JR (ed) Handbook of phycological methods: culture methods and 
growth measurements. Cambridge University Press, Cambridge, NY, p 289-311

Guillard RRL (1975) Culture of phytoplankton for feeding marine invertebrates. In: Smith WL, Chanley MH (eds) Culture of marine invertebrate animals. Plenum Press, New York, p 29-60

Guillard RRL (1995) Culture methods. In: Hallegraeff GM, Anderson DM, Cembella AD (eds) Manual on harmful marine microalgae. IOC manuals and guides No 33, UNESCO, Paris, p 45-62

Hamilton RD (1973) Sterilization. In: Stein JR (ed) Handbook of phycological methods: culture methods and growth measurements. Cambridge University Press, Cambridge, NY, p 181-193

Hobbie JE, Daley RJ, Jasper S (1977) Use of Nuclepore filters for counting bacteria by fluorescence microscopy. Appl Environ Microbiol 33:1225-1228

Hold GL, Smith EA, Birkbeck TH, Gallacher S (2001) Comparison of paralytic shellfish toxin (PST) production by the dinoflagellates Alexandrium lusitanicum NEPCC 253 and Alexandrium tamarense NEPCC 407 in the presence and absence of bacteria. FEMS Microbial Ecol 36:223-234

Lannan CN, Winton JR, Fryer JL (1984) Fish cell lines: establishment and characterization of nine cell lines from salmonids. In Vitro 20:671-676

Lessard EJ (1993) Culturing free-living marine phagotrophic dinoflagellates. In: Kemp PF, Sherr BF, Sherr EB, Cole JJ (eds) Handbook of methods in aquatic microbial ecology. CRC Press, Boca Raton, FL, p 67-75

Lombard EH, Capon B (1971) Observations on the tidepool ecology and behavior of Peridinium gregarium. J Phycol $7: 188-94$

Lovko VJ, Vogelbein WK, Shields JD, Haas LW, Reece KS (2003) A new larval fish bioassay for testing the pathogenicity of Pfiesteria spp. (Dinophyceae). J Phycol 39:600-609

Marshall HG, Gordon AS, Seaborn DW, Dyer B, Dunstan WM, Seaborn M (2000) Comparative culture and toxicity studies between the toxic dinoflagellate, Pfiesteria piscicida and a morphologically similar cryptoperidiniopsoid dinoflagellate. J Exp Mar Biol Ecol 225:51-74

Noga EJ (1987) Propagation in cell culture of the dinoflagellate Amyloodinium, an ectoparasite of marine fishes. Science 236:1302-1304

Noga EJ (2000) Skin ulcers in fish: Pfiesteria and other etiologies. Toxicol Pathol 28:807-823

Noga EJ, Bower CE (1987) Propagation of the marine dinoflagellate Amyloodinium ocellatum under germ-free conditions. J Parasitol 73:924-928

Noga EJ, Smith SA, Burkholder JM, Hobbs C, Bullis RA (1993) A new ichthyotoxic dinoflagellate: cause of acute mortality in aquarium fishes. Vet Rec 133:96-97

Noga EJ, Khoo L, Stevens JB, Fan Z, Burkholder JM (1996)

Editorial responsibility: David A. Caron,

Los Angeles, California, USA
Novel toxic dinoflagellate causes epidemic disease in estuarine fish. Mar Pollut Bull 32:219-224

Oestmann DJ, Lewis DH (1995) A method for producing microbe-free Amyloodinium ocellatum (Brown) with Percoll $^{\circledR}$. Vet Parasitol 59:169-175

Oestmann DJ, Lewis DH (1996) Improved cell culture propagation of Amyloodinium ocellatum. Dis Aquat Org 24:173-178

Parrow MW, Burkholder JM (2003a) Estuarine heterotrophic cryptoperidiniopsoids (Dinophyceae): life cycle and culture studies. J Phycol 39:678-696

Parrow MW, Burkholder JM (2003b) Reproduction and sexuality in Pfiesteria shumwayae (Dinophyceae). J Phycol 39: $697-711$

Parrow M, Burkholder JM, Deamer NJ, Zhang C (2002) Vegetative and sexual reproduction of Pfiesteria spp. (Dinophycea) cultured with algal prey, and inferences for their classification. Harmful Algae 1:5-33

Pringsheim EG (1946) Pure cultures of algae. Cambridge University Press, London

Quesenberry MS, Saito K, Krupatkina DN, Robledo JAF and 11 others (2002) Bioassay for ichthyocidal activity of Pfiesteria piscicida: characterization of a culture flask assay format. J Appl Phycol 14:241-254

Schnepf E, Deichgräber G (1983) 'Myzocytosis', a kind of endocytosis with implications to compartmentation in endosymbiosis. Observations in Paulsenella (Dinophyta). Naturwissenschaften 71:218-219

Shilo M, Aschner M (1953) Factors governing the toxicity of cultures containing the phytoflagellate Prymnesium parvum Carter. J Gen Microbiol 8:333-343

Springer JJ, Shumway SE, Burkholder JM, Glasgow HB (2002) Interactions between the toxic estuarine dinoflagellate Pfiesteria piscicida and 2 species of bivalve molluscs. Mar Ecol Prog Ser 245:1-10

Sullivan BE, Andersen RA (2001) Salinity tolerances of 62 strains of Pfiesteria and Pfiesteria-like heterotrophic flagellates (Dinophyceae). Phycol Res 49:207-214

Turley CM (1993) Direct estimates of bacterial numbers in seawater samples without incurring cell loss due to sample storage. In: Kemp PF, Sherr BF, Sherr EB, Cole JJ (eds) Handbook of methods in aquatic microbial ecology. CRC Press, Boca Raton, FL, p 143-147

Ucko M, Elbrächter M, Schnepf E (1997) A Crypthecodinium cohnii-like dinoflagellate feeding myzocytotically on the unicellular red alga Porphyridium sp. Eur J Phycol 32: 133-140

Vogelbein WK, Shields JD, Haas LW, Reece KS, Zwerner DE (2001) Skin ulcers in estuarine fishes: a comparative pathological evaluation of wild and laboratory-exposed fish. Environ Health Perspect 109:687-693

Wetzel RG, Likens GE (1991) Limnological analyses, 2nd edn. Springer-Verlag, New York

Submitted: October 4, 2004; Accepted: January 21, 2005

Proofs received from author(s): March 29, 2005 